\title{
OBITUARY
}

\section{Remembering Carlos S. Alvarado}

Alfonso Martínez-Taboas

Interamerican University, Puerto Rico

https://doi.org/10.31275/20212031

Creative Commons License CC-BY-NC

I have remote but clear memories about the first time that I met Carlos S. Alvarado. It was in 1972. He was 17 and I 19 years old. Let me explain how we met at so young an age. In 1972 I was a member of the Society for Psychical Research (SPR). By that time, I was intellectually precocious and already had about 200 books and many journals on

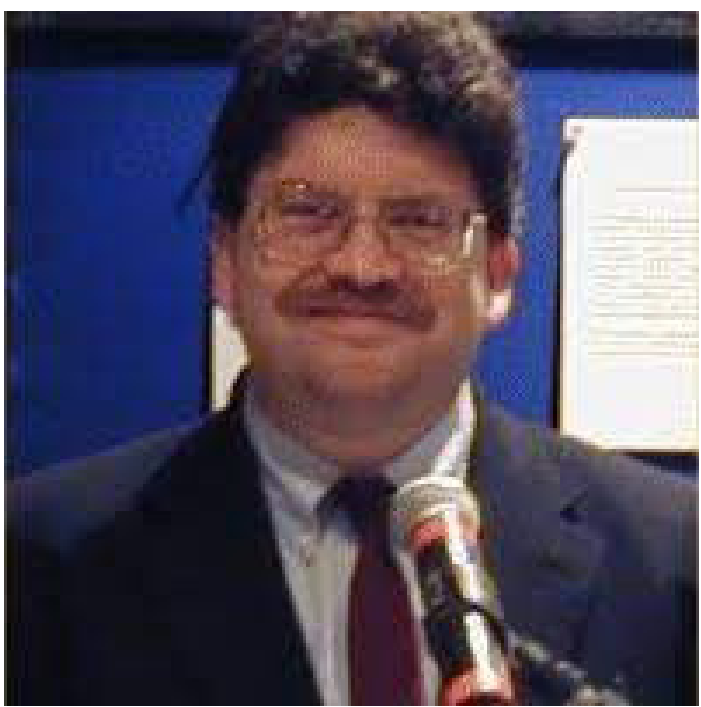
psychical research and parapsychology. However, I felt completely alone: Nobody in Puerto Rico seemed to know the academic literature on those subjects. Therefore, I wrote to the secretary of the SPR asking if there was another member in Puerto Rico. At last! Yes! A person by the name of Carlos S. Alvarado. My first reaction was of total elation. However, on second thought, I was nervous and hesitant. I expected to meet a much older person who, seeing my young age, would dismiss me.

So I wrote Carlos a long letter where I explained that I was a young person but with a very serious approach to parapsychology. Rapidly he 
replied to me (remember, by mail; there was no email then). He really surprised me when he told me that he was nearly two years younger than I was! Not only that, our mothers had been friends when they were younger!

So, in that way, a friendship that extended for 49 years began. In this obituary, I want to concentrate my comments on those early years that were important in Carlos' decision to study parapsychology and to dedicate his intellectual life to the subject.

In the 1970 S Carlos became my best friend. Every Saturday I visited him at his home and played chess (I never won) and we talked about the latest books or journals that he or I had acquired. In a letter that I wrote to him in 2012 I mentioned that I was remembering all the good times together. He wrote me back: "I too have good memories of our friendship and interactions. Do you remember when we played chess? ... Many other memories have come to my mind as I write this."

A curious aspect of our interest in parapsychology was that both of us were especially interested in the study of mediums (both physical and mental) and in spontaneous cases. Of all the mediums that we discussed, the one that seized our attention was Eusapia Palladino. Therefore, we began to collect a lot of information about Eusapia. We shared a very positive outlook on her physical phenomena. In addition, we were curious and impressed by the work of Dr. Ian Stevenson. We both took a special interest in his work with reincarnation cases and telepathic impressions.

Approximately in 1973 we decided to publish a journal on psychical research with the name Explorando lo Paranormal (Exploring the Paranormal). The journal was important for us, as it permitted us to elaborate on our thinking about the subject and receive feedback from other professionals interested in parapsychology.

One of our favorite authors at that time was D. Scott Rogo. That was precisely because Rogo's approach was consistent with our interests. Rogo wrote extensively about mediumship, poltergeists, and spontaneous cases. In addition, we were truly impressed by his historical knowledge of the field. We both enjoyed reading his book: Parapsychology: A Century of Inquiry (1975). Therefore, when Rogo was killed in 1990 we both were deeply saddened by his untimely death at the age of 40 . 
With Carlos I shared very special moments. We wanted to document or see some paranormal phenomena. Therefore, we both investigated some spontaneous apparitional cases, a poltergeist case, visited and slept at a haunted house, and, with a group of people interested in UFOs, we slept in desolate mountains where it was said that there were UFO landings. Despite all our efforts, we never encountered a single paranormal event that convinced us.

It is important to mention that Carlos' father was a well-known public figure in Puerto Rico, especially in certain political parties. His father was truly interested in the education of his two sons. In fact, Carlos' brother (Alberto) studied architecture and eventually worked with his father. However, Carlos was more inclined to the social sciences. Therefore, he completed his BA in psychology at the University of Puerto Rico. He was fortunate enough that by that time there was an elective course on parapsychology, so he took it and he discovered that he was more knowledgeable about the field than the professor was. After finishing his BA in psychology, Carlos told me that he would not study clinical psychology, because he was not interested in psychotherapy. His real interest was in parapsychology. Therefore, he communicated his decision to his father and mother. His father was concerned with his decision. He believed that parapsychology was not a prestigious field and he had doubts about the financial future of his son. Nevertheless, he respected Carlos' decision, and always supported him.

By that time (1978), John F. Kennedy University was offering a Master's Degree in parapsychology. Many times we evaluated the possibility that Carlos would move his residency to the USA and his prospects of dealing with a profession that was uncertain in terms of financial and professional prestige. Eventually he decided to study at John F. Kennedy University. I remember that when I saw him leaving Puerto Rico I began to cry in my car. I recognized that our intimate and constant interactions would never be the same. Long-distance relationships are a challenge.

While he was in the USA we communicated by telephone and by letter. Eventually Carlos returned to Puerto Rico. He wanted to reside in Puerto Rico, but soon he discovered that the door to the field of parapsychology was closed there. He went to different research centers 
and universities to offer courses on the subject. Only one university (Carlos Albizu University) offered him the opportunity to give a single introductory course on the subject. Therefore, he became frustrated with the situation in Puerto Rico and eventually understood that he had no chance to progress and prosper on the Island.

I also remember when Carlos and Dr. Nancy Zingrone met in the USA. I believe they began to know each other in 1983. They shared so many interests and developed a unique and extraordinary bonding that lasted until his death. When Carlos talked about Nancy with me, he never expressed any complaints. On the contrary, he admired her intellectually and I can say that she was the love of his life. There is no doubt about that.

I enjoyed writing some articles with Carlos (Martínez-Taboas \& Alvarado, 1981; Alvarado \& Martínez-Taboas, 1983, 2002), and in Puerto Rico we participated in some joint conferences, mostly about spontaneous cases and mediumship. It is no wonder that his only book was on Charles Richet, who was well-known for his interest in mediums and in Eusapia Palladino.

As I write this obituary, I remember Carlos's face. He was usually playful, full of joking comments, and very respectful toward his intellectual opponents. I remember his incisive critical skills, his prodigious memory, and his passion toward the subjects he wrote about. We will remember him for his numerous writings about the history of psychical research and parapsychology. Carlos was one of the most systematic and respected historians in the field of psychical research, in my opinion as prominent as Dr. Alan Gauld. In addition, he will be remembered for his kindness toward all those fortunate persons who knew him. He will be sorely missed.

I close my comments with an anecdote. In the 1970s, Carlos had a stuffed serpent in his room that we called "the boa." We had a lot of fun with it; in fact, the last time that we talked by telephone we joked about it. In my house, I have a wooden serpent made in Indonesia that I also call "the boa." Eight days after Carlos died, the wooden figure of the boa, which is in a secure place, inexplicably fell to the floor. I just thought, is that Carlos communicating with me? I will never be sure. Nevertheless, what is beyond doubt is that I have had the privilege of knowing an excellent man and scholar. 


\section{REFERENCES}

Alvarado, C. S., \& Martínez-Taboas, A. (1983). The super-psi hyphotesis: A review. Theta, 11, 57-62.

Alvarado, C. S., \& Martínez-Taboas, A. (2002). Parapsicología: Falacias y errores que todo psicólogo debe reconocer. [Parapsychology: Fallacies and errors that every psychologist should know]. Revista Puertorriqueña de Psicología, 13, 99-125.

Martínez-Taboas, A., \& Alvarado, C. S. (1981). Poltergeist agents: A review of recent research trends and conceptualizations. European Journal of Parapsychology, 4, 99-110. 